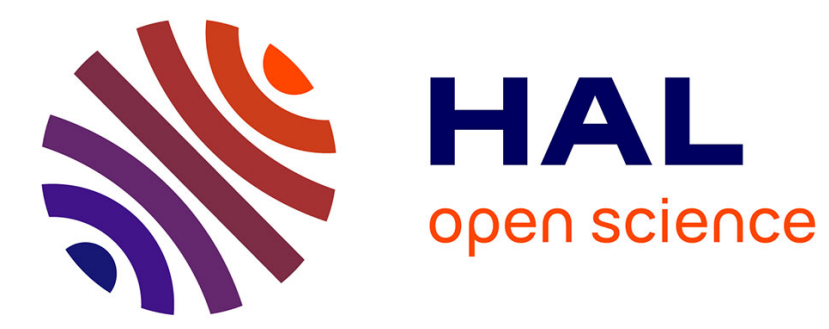

\title{
Human Rights: Ethical, Political... or Legal? First Steps in a Legal Theory of Human Rights
}

\author{
Samantha Besson
}

\section{To cite this version:}

Samantha Besson. Human Rights: Ethical, Political... or Legal? First Steps in a Legal Theory of Human Rights. Donald Earl Childress, III. The Role of Ethics in International Law, Cambridge University Press, pp.211-245, 2011, ASIL Studies in International Legal Theory, 978-0-511-97842-5. 10.1017/CBO9780511978425.013 . hal-02516314

\section{HAL Id: hal-02516314 https://hal.science/hal-02516314}

Submitted on 29 May 2020

HAL is a multi-disciplinary open access archive for the deposit and dissemination of scientific research documents, whether they are published or not. The documents may come from teaching and research institutions in France or abroad, or from public or private research centers.
L'archive ouverte pluridisciplinaire HAL, est destinée au dépôt et à la diffusion de documents scientifiques de niveau recherche, publiés ou non, émanant des établissements d'enseignement et de recherche français ou étrangers, des laboratoires publics ou privés. 


\section{Human Rights: Ethical, Political ... or Legal? First Steps in a Legal Theory of Human Rights}

Samantha Besson

\section{INTRODUCTION}

(International) ${ }^{1}$ human rights theory is en vogue. It has been the case for quite some years in Germany, ${ }^{2}$ (sce fouthote on next page) and it is now also the case in

"Many thanks to Eleonor Kleber Gallego for her help with the formal editing of the present chapter. Drafts of the chapter were presented at the Osgoode Hall Law School's Nathanson Centre Seninar on Legal Philosophy between State and Transnationalism in Toronto on October 16, 2009, at a meeting of the ASIL International Legal Theory Group in Washington, D.C. on November 13, 2009, and at the Duke Law Faculty workshop on December 11, 2009. I thank Allen Buchanan, Trey Childress, Michael Giudice, Larry Helfer, Sophia ReibetanzMoreau, and François Tanguay-Renaud for their comments and critical remarks. Last but not east, many thanks are due to two Cambridge University Press anonymous reviewers for their useful suggestions.

'In the course of the chapter, it will become clear why in view of the interlocking human rights practice and in particular in view of the fact that subjects of international and national human rights are the same and that the locus of application of human rights is domestic in priority - see, e.g., Stephen Gardbaum, "Human Rights as International Constitutional Rights," European Joumal of Intemational Law 19(4) (2008): 749-768 and Gerald Neumann, "Human Rights and Constitutional Rights," Stanford Law Review 55 (2003): 1863-1900 - a theory of humann rights has to be both a theory of domestic and international human rights. This is even more so in the case of a legal theory of human rights, assuming of course that international law can be regarded as law (see for that argument and refutation of different forms of scepticism relative to the legality of intemational law and to ethical thinking about international law, Samantlia Besson and John Tasioulas, introduction to The Philosophy of Intemational Law, ed. Samantha Besson and Jolm Tasioulas, Oxford: Oxford, 2010, 1-27). There should therefore be one concept of human rights that can capture not only their moral and legal dimensions but also their legal guarantees at the domestic, regional, and international levels. For a similar view about the human rights continuum, see Rainer Forst, "The Justification of Human Rights and the Basic Right to Justification. A Reflexive Approach," Ethics 120 (2010): 711-740 (depending on the existence of a political system, whether domestic or international). For human rights theories that focus exclusively on international (legal or political) human rights, see John Rawls, The Law of Peoples (Cambridge, MA: Harvard, 1999); Charles R. Beitz, The ldea of lluman Rights (Oxford: Oxford, 2009); Joseph Raz, "Human Rights without Foundations," in Besson and Tasioulas, The Philosophy of International Law, 321-337; 
Anglo-American circles. ${ }^{3}$ One of the very first issues a human rights theorist is expected to address is the nature of human rights and, hence, of human rights theory.

The nature of human rights theory is an important concem for at least two reasons. First of all, thinking about the nature of human rights theory situates it within a broader set of theories, in particular legal theory, democratic theory, or theories of justice, and can generate beneficial comnections between them. Too often, human rights theorists fail to reveal those links, and the credibility of their theories is partly undermined by the artificial severance of those connections given the centrality of human rights to human individual and

Joseph Raz, "Human Rights in the Emerging World Order," Transnational Legal Theory 1:1 2010): 31-47. For human rights theories that focus on human rights independently from any political or legal system, whether national or intermational, see John Tasioulas "Are Humn Rights Essentially Triggers for Interention?" Philophe

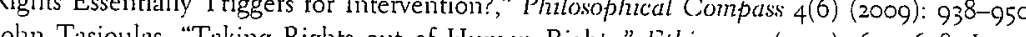
John Tasioulas, "Taking Rights out of Human Rights," Ethics 120 (2010): 647-678; James Griffin, On lluman Rights (Oxford: Oxford, 2008).

See, e.g., Robert Alexy, Theorie der Crundrechte, 3rd ed. (Frankfurt: Sulıkamp, 19g6); Stefan Gosepath and Georg Lohmann (eds.), Die Philosophie der Mensschenrechte, znd ed. (Frankfurt: Sulurkamp, 1999); Heiner Bielefeldt, Philosophie der Menschenrechte. Crundlagen eine weltweiten Freiheitsethos (Darmstadt: Primus, 1998). Hauke Brunlthorst, Wolfung R Koller, and Matthias Lutz-Bachmann (eds.), Recht auf Menschenrechte (Frankfurt: Sulhrkamp, 1999) Karl-Peter Fritzsche and Georg Lohmann (eds.), Menschentechte zwischen Anspruch und Wirklichkeit (Würzburg: Ergon, zooo); Georg Lohmann et al., Die Menschrechte: Unteilbar und Cleichgewichtig? (Potsdan: University Press, 2005); Rainer Forst, Das Recht auf Rechtfertigung. Elemente einer kunstruktivistischen Theorie der Cerechtigkeit (Frankfurt: Suhrkamp, 2007); Christoph Menke and Arnd Pollnann, Philosophie der Menschenrechte. Zur Einfïhrung (Hamburg: Junius Verlag, 2007); Karl-Peter Fritzsche, Menschenrechte, and ed. (Paderborn Ferdinand Schöningh, 2009).

${ }^{3}$ See, e.g., Henry Shue, Basic Rights: Subsistence, Affuence and US Foreign Policy, nnd ed (Princeton, NJ: Princeton, 1996); Rawls, The Law of Peoples; Allen Buchanan, Justice, Legitimacy, and Self-Determination: Moral Foundations for International Law (Oxford: Oxford, 2004); James W. Nickel, Making Sense of Human Rights, and ed. (Oxford: Blackwell, 2007); Michael J. Perry, Troward a 'Theory of Human Rights: Retigion, Law, Courts (New York. Cam-

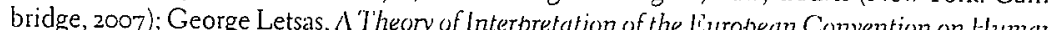

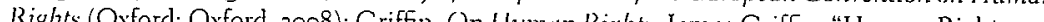

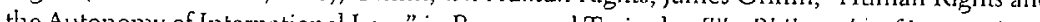
the Autonomy of International Law," in Besson and Tasioulas, The Philosophy of International 1,aw, 339-355; John Tasioulas, "Human Rights, Universality and the Values of Personlıood: Retracting Griffin's Steps," Wuropean foumal of Philosophy 10 (2002): 79-100; John Tasioulas, "The Moral Reality of Human Rights," in Thomas Pogge (ed.), Freedom from Poverty as a Human Right: Who Owes What to the Very Poor (Oxford. Oxford, 2007 ) 75-1, Tajo "Are Human Rights Essentially Triggers for Intervention?," Tasioulas, "Taking Rights out of

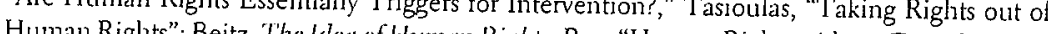
Human Rights"; Beitz, The lded of Human Rights; Raz, "Human Rights without Foundations"; Raz, "Human Rights in the Emerging World Order." See also the special issue of Ethics 120 (2010) edited by Allen Buchanan on Griffn's book (Griffin, On Human Rights); and Charles R. Beitz and Robert Goodin (eds.), Clobal Busic Rights (Oxford: Oxford, 2009), an edited collection assessing the impact of Shue's book (Shue, Basic Rights) thirty years after the puliond collecof its first edition. social life. Second, thinking about the nature of theory requires a preliminary clarification of what it is a theory of and, therefore, of the nature of human rights. ${ }^{4}$ Such a preliminary consideration can prove very beneficial in fully identifying or at least delineating the object of one's theoretical endeavor. The answers to many of the important questions that human rights theorists identify as being central to human rights theory, particularly the existence, function, content, weight, scope, and justification of human rights, are conditioned by the theorists' original characterization of the nature of their theory and its object. Finally, some human rights theorists may even want to argue that human rights theorizing is part of human rights practice and of their object of study as a consequence. 5 This implies in turn that the nature of human rights theory should not escape their meta-theoretical attention.

More specifically, it is the relationship between the law and the morality or ethics ${ }^{6}$ of human rights, and, hence, between the moral and legal theories of human rights, that I will be concened with in this chapter. Of all areas of international law, international human rights law is the most likely to trigger questions pertaining to the role of ethics in the practice and theory of international law. This is because the content of international legal human rights and that of their moral correspondents are often taken to overlap - or because their validity and justification is sometimes taken to transcend their legal enactment, at least on the face of international human rights instruments' preambles or judicial reasoning on those grounds. ${ }^{7}$ As a matter of fact, recent human rights theories seem to be focusing almost exclusively on the moral nature of human rights. ${ }^{8}$ Those few accounts that have distanced themselves from this form of abstract ethical theorizing about human rights are grounded on purely political practices, of which the law is just one instantiation. ${ }^{9}$ As a result, most recent human rights theories have not only neglected the specifically legal dimension of human rights, but also have artificially severed the links between human rights theory and legal theory. Curiously, therefore, they

+ See Raz's reflections on the nature of legal theory and hence on the nature of law and of the concept of law: Joseph Raz, "Can There be a Theory of Law," in his Between Authority and Interpretation (Oxford: Oxford, 2009), 17-46.

${ }_{5}$ Traces of this Dworkinian approach to legal theory may be found in Beitz, The Idea of Human Rights, 8-9, 212 (coutra 105, though).

${ }^{6}$ I will use both terms interchangeably in this chapter.

7 See James Nickel and David Reidy, "Philosophical Foundations of Hunan Rights," in Daniel Moeckli et al. (eds.), International Human Rights Law (Oxford: Oxford, 2010), 39-63.

${ }^{8}$ See, e.g., Nickel, Making Sense of Human Rights; Griffin, On Human Rights; Griffin, "Human

Rights and the Autonomy of International Law"; Tasioulas, "Are Human Rights Essentially

Triggers for Intervention?"; Tasioulas, "Taking Rights out of Human Rights."

` See, e.g., Rawls, The Luw of Peoples; Beitz, The ldea of Human Rights; Raz, "Human Rights without Foundations"; Raz, "Human Rights in the Emerging World Order." 
seem to have tumed the present volume's topic on its head: It is not so much the role of ethics in international law, but the role of law itself in ethical and nonethical theories of international human rights that ought to be in question.

This legal gap in human rights theory should not come as a surprise given the current state of the philosophy of international law. Until recently, there has been little faith in the legality of intemational law and the role of normative theorizing about it. ${ }^{\circ}$ Very schematically, international law has been, alternatively and in a stark contrast, entirely assimilated either into ethics by international natural lawyers or into a sum of state interests by realist, postmodem, or voluntarist international lawyers. Human rights theory does not seem to have escaped this regrettable state of affairs. Assessing the reasons for this legal blind spot in current human rights theorizing and the ways to remedy it will be my concen in this chapter. Most contemporary human rights theorists ${ }^{11}$ do not spend much time theorizing about the nature of their theory and, more specifically, about the legal dimensions of that theory. ${ }^{12}$ This is surprising,

${ }^{10}$ See Besson and Tasioulas, "Introduction."

"I will be focusing on recent Anglo-American human rights theories in this chapter and in particular on Buchanian, Justice, Legitimacy, and Self-Determination; Nickel, Makino Sense of Human Rights; Griffn, On Human Rights; Griffin, "Human Rights and the Autonony of International Law"; Tasioulas, "Are Human Rights Essentially Triggers for Inenvent;

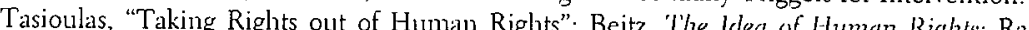
"Hasioulas, Taking Rights out of Human Rights"; Beitz, The ldea of Human Rights; Raz, "Human Rights without Foundations"; and Raz, "Human Rights in the Emerging World

${ }^{12}$ In the German tradition, by contrast, important and influential legal or moral-legal theories of human rights were developed early on; see, in particular, Alexy, 'Theorie der Cinundrechte. Jürgen Habermas, "Die Legitimation durch Menschenrechte," in Die postnationale Konstllation Politische Essays (Frankfurt: Suhrkamp, 1998), 170-192; and Rainer Forst, "The Basic Right to Justification: Toward a Constructivist Conception of Human Rights," Constellations 6(1) (1999): 35-60. Those theories, however, are theories of domestic humant rights and those author have found it difficult to transpose their theories to international human rights; see Habermas, "Die Legitimation durch Menschenrechte"; Jürgen Habermas, "Hat die Konstitutionalisierung des Völkerrechts noch eine Chance?" in Der gespaltene Westen (Frankfurt: Sulhrkamp, 2004) 113-192; and Cohen's critique, i.e., Jean L. Cohen, "Rethinking Human Rights, Democracy and Sovereignty in the Age of Clobalization," Political Theory $36(4)$ (2008): $578-606$, 59 600 . There are a few excetions to the absence of refer $30(4)$ (2008): 578-606, 599 600. There are a few exceptions to the absence of reference to law in recent Anglo-American theories of (intemational) human rights. See, in particular, Buchanan, Justice, L.egitimacy, and Self-Determination; Başak Cali and Saladin Meckled-Garcia, "Introduction: Human Rights Legalized - Defining, Interpreting and Implementing an Ideal," in Başak Cali and Saladin Meckled-Garcia (eds.), The Legalization of Human Rights, Multidisciplinarity Perspectives on Human Rights and I luman Rights Law (London: Routledge, 2006), 1-8. Amutya Sen "H Rights and the Limits of Law, $\mathrm{O}$ Idea of (ustice (C) Idea of /ustice (Cambridge, MA: Harvard, 2009), Chapter 17; Perry, Toward a T'heory of Human Rights; Letsas, A Theory of Interpretation; Cohen, "Rethinking Human Rights"; Forst, "The Justification of Human Rights"; Allen Buchanan, "Plilosophical Theories of Human Rights," in David Estlund (eds.), The Oxford Handbook of Political Philosophy (Oxford: Oxford, 2011),
forthcoming. because the concept of human rights itself is usually regarded as being a moral, a political, and a legal concept. ${ }^{13}$ True, human rights theorists disagree about whether human rights theory should be (in part or exclusively) about conceptual analysis. ${ }^{14}$ Further, although one may understand why a moral philosopher or a political scientist may not want to reduce human rights qua moral standards or political practice to legal rules and principles, understanding the legal dimension of those standards or practice or their interaction with the law of human rights would seem to be an important part of the elucidation of their broader moral and political nature. ${ }^{15}$ Human rights constitute a complex normative practice that combines moral, political, and legal elements, and all three ought to be accounted for.

One explanation for the legal neglect in human rights theory may lie in a fundamental distinction made in all or most recent human rights theories: the opposition between the concrete practice of human rights and the abstract standards of human rights. ${ }^{16}$ In fact, most human rights theorists identify that opposition as central to their account and situate the legal cuestion in that opposition. They usually claim they are (also) writing about human rights as a legal and political practice and not (only) about human rights as abstract moral standards. Doing so, most of them want to distance themselves from a top-down approach and choose instead a practice-oriented or bottom-up approach, ${ }^{17}$ or what they sometimes refer to as a "middle-game" or "middle-level"

${ }^{13}$ Raz, "Human Rights without Foundations," 336-337 focuses, for instance, on the use of the tern "human rights" in legal and political practice and cliscusses various conceptions. $\mathrm{H}$ claims, however, that he has not "offered an analysis of the concept of a human right." There is not enough cliscipline underpinning the use of the term "human rights" to make it a useful analytical tool, he argues. According to him, "[t]he elucidation of its meaning does no illuminate significant ethical or political issues" (emphasis added).

4 Following Raz, "Can There be a Theory of Law," 18, I understand concepts as being intermediaries between the world, aspects of which they are concepts of, and terms that express then and are used to talk about those aspects of the world.

is This explains why the explanation according to which human rights theorists may actually not 15 This explains why the explanation according to which human rights theorists may actually not
be talking about the same thing as human rights lawyers and legal theorists of human rights fails: All human rights theorists factor in human rights practice at one place or the other in their account of human rights and see the law as part of that practice.

${ }^{16}$ Other explanations may range from sheer ignorance or lack of interest about the law and legal theory, or skepticism about the legality of international law (including international human rights law), to strong views about the law's autonomy or nonautonomy from morality, or about legal rights' autonomy or nonautonomy from moral rights. At though some or all those positions may be justifiable and apply depending on the author, spelling out their justifications would make ethical or political accounts of human rights more transparent and arguably more convincing overall.

${ }^{17}$ See, e.g., Beitz, 'The Idea of Human Rights; Raz, "Human Rights without Foundations," $322-$ 327 
approach. 8 The problem with those "political" or practical theories, however, is that they usually fail to explain how they get to the moral stance from which they can then criticize their practical account. The other group of theorists does not fare much better, however. The theorists who belong to that group have interestingly portrayed themselves as writing from a bottom-up approach. ${ }^{19}$ They are not regarded by their critiques as having succeeded to escape top-down theorizing, however, and are coined as "ethical" or traditional accounts of human rights. ${ }^{20}$ When read carefully indeed, they refer to human rights practice at most as a test case ${ }^{21}$ for their theoretical proposal or as something to criticize or guide from that perspective. ${ }^{22}$ As a result, and prima facie, neither of those two approaches succeeds in bridging the gap between human rights standards and human rights practice. The former fail to explain how they can construct a human rights account from legal practice and then criticize it from an abstract moral stance. ${ }^{23}$ The latter are unclear about how they can focus on abstract standards distinct from human rights practice and then be faithful to the legal practice on that basis. ${ }^{24}$

One of the reasons for the difficulties that human rights theorists have in bridging the gap between standards and practices lies, arguably, in their failure to take into account the inherently legal nature of human rights ${ }^{25}$ or at least to understand it fully. ${ }^{26}$ They actually assume they have taken the legal dimension

is See, e.g., Nickel, Making Sense of Human Rights, 3. See also Beitz, The Idea of Human Rights,

127, 212.
"See, e.g., Griffin, On Human Rights, 29; Tasioulas, “Are Human Rights Essentially Triggers for Intervention?," 939.

20 See the critiques by Beitz, The ldea of Human Rights, $7 \mathrm{fn} .12$.

"See Tasioulas, "Are Human Rights Essentially Triggers for Intervention?", 939; Tasioulas, "Taking Rights out of Human Rights."

${ }_{22}$ See Griffn, On Human Rights, 204, 209-211.

${ }^{23}$ This is one of the problems with the two-step approach in Beitz, The Idea of Human Rights. $11,102-106,126-128$

24 This is one of the problems with the notion of "Gidelity" to human rights practice in Griffin, On Human Rights, 29; Tasioulas, "Are Human Rights Essentially Triggers for Intervention?", Even a Dworkinian reading of that notion would not help here, as the two steps in Dworkin's conception of legal interpretation do not correspond to a divide between moral reasoning on the one hand and legal reasoning on the other See Jeremy Waldron, "Judges as Moral Reasen " Intumational Reasoners," International Journal of Constitutional Law 7 (2009): 2-24, 12; Ronald Dworkin Letw's Limpire (Cambridge, MA: Harvard, 1986), 256.

${ }^{25} \mathrm{See}$, e.g., Griffin, On Human Rights, 191, who opposes "philosophical theory" to "legal practice"; Tasioulas, "The Moral Reality of Human Rights," $84-85$. Nickel Makino Senze of Hum Rights, 32-33, who conflates the distinction between monal and legal rights with that betwe ${ }^{26}$ See, e. Beitz The lded or enforceable riglits; Sen, The ldea of /ustice, $364-366$

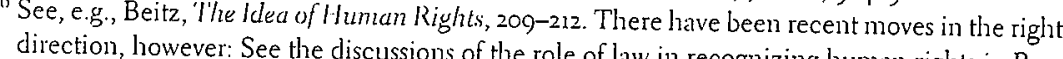
direction, however: See the discussions of the role of law in recognizing human rights in Raz, "Human Rights in the Emerging World Order"; and Colhen, "Rethinking Human Rights," $599-600$ of human rights into account by making the opposition between human rights practice and human rights standards a central part of their theoretical poise on human rights. In fact, what they have done is reduce law to one side of the equation by conflating it with one of the dimensions of human rights politics or practice. No wonder, in those conditions, that human rights law is regarded by those authors as playing a secondary role, if at all, in human rights theory. It is inportant, however, not to confuse the relationship between abstract standards and concrete practice, on the one hand, with the relationship between human rights as ethical or moral standards and human rights as legal norms, on the other. It is true that human rights law can play a crucial role in the enforcement of human rights standards in practice by specifying human rights and duties. ${ }^{27}$ Nonetheless, it can also contribute to the identification and specification of those standards at an abstract level, either through the recognition of interests as sufficiently fundamental to give rise to rights and cluties, or through the recognition of preexisting moral rights. The difficulties that beset the opposition between bottom-up and top-down approaches on the one hand and the complex relationship between facts and norms in the legal practice on the other are well known to legal theorists. They have long learned to explain the law qua normative practice.

It seems, therefore, that by not paying sufficient attention to the legal nature of human rights and by conflating the law of human rights too quickly with their politics or practice, current human rights theories miss on a central component of the normative practice of human rights, thus impoverishing their moral account of human rights. Worse, they deprive themselves from essential theoretical insights about the nature of normative practices and, hence, of resources in their efforts to bridge the gap between human rights as critical moral standards and the political practice of human rights. The point of this chapter is to show how legal theory can provide a useful resource in the light of which many of our current discussions in human rights theory could be more fruitfully held. ${ }^{28}$

${ }^{27}$ The role of legal human rights in this respect is best captured by Nickel, Making Sense of Human Rights, 45-48, 187-188

${ }_{20}$ Even though the present chapter proposes a legal theory of human rights as legal norms, it does not claim to artificially separate law from morality and from politics. On the contrary, it proposes a normative theory of human rights law based on a republican theory of law; see Samantha Besson and José Luis Martí, "Law and Republicanism: Mapping the Issues," in their Legal Republicanism: National and International (Oxford: Oxford, 2009), 3-39. Legal positivist accounts of this kind recognize deep and diverse relationships between legal validity and legitimacy on: the one hand and morality on the other, see, e.g., Joseph Raz, "About Morality and the Nature of Law," The American Joumal of Jurisprudence 48 (2003): 1-15; Joseph Raz, "Incorporation by Law," Legal 'Theory 10 (2004): 1-17. This is clearly the case in the freld of "rights," as we will see. 
My argument unfolds in two steps. I start by mapping current ethical and political human rights theories and assessing how the legal dimensions of human rights are understood in each of them. In the second section, I challenge the divide between ethical and political accounts of human rights by reference to the legality of human rights. To briclge the gap between those accounts, I argue for a moral-political account of the nature of humann rights and, on that basis, explain the intrinsic relationship between moral and legal
human rights.

\section{THE LAW IN EXISTING HUMAN RIGHTS THEORIES}

Here I present the two main groups of human rights theories that have arisen in recent years. Those theories have pigeon-holed each other as "ethical" and "political" theories of human rights.

When presenting the accounts that fall in either category, my aim is not to do so generally or exhaustively, but to identify how the legal dimension of human rights is addressed within each of them. Interestingly, both ethical and political theories of human rights share a similar neglect for the legal dimension of human rights. This is surprising, because it is precisely the concen for fidelity to the practice of human rights, including, presumably, their legal practice that is said to lie at the core of their division. It is even more surprising because some of those human rights theorists have developed fully fledged theories of law elsewhere, or even, in some cases, a full theory of legal rights.29 Remedying the neglect of the legal dimension of human rights may actually help bridge the divide between those two groups of human rights theories, as I argue in the second section.

Because of the great variation of adjectives that have been used to describe and qualify the different theories of human rights currently in discussion, it may be useful to clarify how I understand them in this chapter. The qualifications "ethical" and "political" have been used to oppose theories of human rights on three different issues: the nature of human rights, their function, and their justification. ${ }^{30}$ Although it may have been the case at first that the theories that fell into either of those two categories did indeed have opposed views on those three central issues, views that could be qualified either as political or ethical, it is no longer necessarily the case. There are examples of human rights theorists whose view of the function of human rights is political but

\footnotetext{
21) This is the case in Raz, "Human Rights without Foundations." See, however, Raz, "Human
Rights in the Emerging World Order."

30 See on those uses, e.g., Tasioulas, "Are Human Rights Essentially Triggers for Intervention?";

Tasioulas, "Taking Rights out of Human Rights"; Forst, "The Justification of Human Rights."
}

whose account of their justification is ethical, thus providing for a moralpolitical account of human rights. ${ }^{31}$ In what follows, I use those two categories to capture a difference of views pertaining to the nature of human rights exclusively, and not their function or justification. It is precisely with respect to the nature of human rights that the realization of their legal dimension is most instructive; not only does it bridge the divide between the ethical and the political conceptions of human rights, but it sheds light on how human rights law can both implement and mold human rights standards and, hence, on how ethics and politics interact in this context. This, in turn, necessarily impacts on the function and justification of human rights.

\section{A. Ethical Theories of Human Rights and the Law}

Ethical theories of human rights understand human rights as ethical norms that may or may not be legalized within domestic or international law. For those theories, human rights law is only a concern in a second stage, after the existence and content of human rights have been clarified and need to be either legally enacted or enforced. In this section I look more closely into two of the most influential ethical theories: those of James Griffin and John Tasioulas. ${ }^{32}$

James Griffin's book On Human Rights conceives humann rights as universal ethical norms. He mentions the legal dimension of human rights briefly in Section 2.1 and addresses it again in Chapter 11 of his book. ${ }^{33}$ His argument is that there are discrepancies between the best philosophical (ethical) account of humann riglts (his) and international law's lists of human rights. ${ }^{34}$ According to him, those discrepancies ought to be corrected by philosophers who can help international lawyers and judges, in particular, grasp the existence conditions of human rights, incorporate those rights into international positive law, or at least make their substantive meaning more determinate. 35 As a result, even though Griffin seems to be claiming that his account is bottom up and starts from human rights practice, it does not seem to differ so much from a topdown approach that aims at fitting how the notion of human rights is used in social life. ${ }^{36}$

${ }^{31}$ See, e.g., Forst, "The Justification of Human Rights," who describes tyis own account as being ethical-political.

${ }^{32}$ See also Sen, The lded of /ustice, Chapter 17

33 Griffn, On Human Rights. See also James Griffn, "First Steps in an Account of Human Rights," European Journal of Philosophy 9, (2001): 306-327; and Griffin, "Human Rights and the Autonomy of Intemational Law."

34 Griffin, On Human Rights, 191-202.

35 Griffin, On Human Rights, 204, 200-211.

${ }^{36} \mathrm{See}$ Griffin, On Hunzan Rights, 29. See the critique to the same effect in Beitz, The Idea of Human Rights, 7 fin. 12. 
As a result, Griffin's account of the legal dimension of human rights and his account of human rights in general can be deemed incomplete. To start with, Griffin locates the law exclusively in the practice of human rights, and he sees that practice as having to be aligned with the best philosophical account of human rights. This explains why he devotes a single chapter to the legal question, and a chapter that is situated at the end of the book, once his philosophical account of human rights has been spelled out. Another difficulty with Griffin's account of legal human rights, and one that is actually difficult to reconcile with the idea of law as practice only, has to do with what one may refer to as his closet natural law theory. ${ }^{37}$ It is not the applicability of natural law theory to human rights that is at issue here. Rather, the problem is the lack of argument for Griffin's take on one of the most difficult issues in legal theory: the relationship between legal validity and moral correctness on the one hand and between legal and moral reasoning, especially in the context of judicial reasoning about rights, on the other. $3^{8}$ Reducing legal human rights to a blanket incorporation of moral rights into the law, 39 and judicial reasoning with rights to moral reasoning, is too quick and simplistic, and something contemporary natural lawyers would not endorse. $4^{\circ}$ A third difficulty with Griffin's understanding of the legal dimension of human rights pertains to his downplay of the rights dimension of human rights. ${ }^{41}$ Because he does not conceive of human rights as rights that generate duties, the legal questions that usually arise out of conflicts of rights (and duties) and their claimability do not appear in Griffin's account. A final difficulty with Griffin's account of the legal dimension of human rights has to do with his understanding of the legal

${ }^{37}$ See Griffin, On Human Rights, 204, in which the author discusses the "incorporation" of humann rights, and 203, in which he discusses the "rule of recognition" of international human rights law. He then goes on to discuss its "bindingness" $(205)$, but the legitimate authority of international human rights law is an altogether different question from that of their legal content and validity. See, e.g.. Samantha Besson, "The Legitimate Authority of their legal Human Rights," in Andreas Follesdal (ed.), The Legitimacy of the Intemational Huternational System (Cambridge: Cambridge, 2012), forthcoming. $3^{8}$ System (Cambridge: Cambridge, 2012), forthcoming.

See, e.g., the recent debate between Waldron, "Judges as Moral Reasoners"; Wojciech Sadurski, "Rights and Moral Reasoning: an Unstated Assumption - A Comment on Jeremy Waldron's 'Judges as Moral Reasoners," Intemational joumal of Constitutional Law $7(1)$ (2009): 25-45; and Jeremy Waldron, "Refining the Question about Judges' Moral Capacity" International fournal of Constitutional Law 7 (2009): 69-82. See also Joseph Raz "Reacon, with Rules," Current Legal Problemss 54 (2001): 1-17, on the specific moral nature of legal

39) See Griffin, On I luman Rights, 38.

${ }^{40}$ For instance, Dworkin's conception of legal interpretation does not correspond to a moral reasoning versus legal reasoning divide (see Waldron, "Judges as Moral Reasoners," 12; Ronald
Dworkin, Law's Limpire, 256).

+ See the criticque by Tasioulas, "Taking Rights out of Human Rights." practice of international human rights. The authors he quotes as international human rights lawyers are either philosophers, or realist international lawyers who by definition are skeptical about both the legality of international law (and human rights) and the role of ethics in international law (and human rights). $4^{2}$ By obliterating the writings of mainstream human rights lawyers and intemational legal theorists, Griffin's line of argument comes close to a Philosopher King's argument.43

John Tasioulas's work on human rights was initially built on James Griffin's.44 His account is an ethical or traditional one in the sense that he regards human rights as universal moral rights that belong to all human beings by virtue of their humanity and that may or may not be legalized within domestic or intemational law.

In recent papers, and in the course of his critique of political accounts proposed by Rawls, Raz, or Beitz, Tasioulas has gradually distanced himself from Griffin's theory. ${ }^{45}$ In that context, he offers a potentially richer account of the legal dimension of human rights. One of his main critiques against Griffin is that he has taken rights out of human rights, thus losing touch with a solid body of research on moral rights. ${ }^{6}$ This presumably could be taken to mean that the work legal theorists have done on legal rights and their relationship to moral rights could also be fruitfully referred to when theorizing human rights. Regrettably, Tasioulas does not quote legal theorists' work on rights, however, which is surprising given the more intimate commection there is between moral and legal rights than between other moral and legal concepts. 47 Elsewhere, Tasioulas considers fidelity to post-1945 human rights culture as it has crystallized in major international human rights instruments as a criterion for the adequacy of any human rights theory..$^{8} \mathrm{He}$ quickly adds, however, that fidelity is a complex notion and that it would have to be compatible with adopting a critical perspective on human rights, so as not to rubber-stamp any human rights legal guarantees. Sadly, he does not provide more details as to

+2 See Griffin, On Human Rights, 309 fn. 18 (quoting Allen Buclanan on legitimate authority) and 19 (quoting Eric Posner on state interests).

43 See Griffin, On Human Rights, 209-210 about the "solitary philosopher" and the responsibility of philosophers and political theorists.

* See, e.g., Tasioulas, "Human Rights, Universality and the Values of Personhood: Retracting Griffin's Steps."

${ }^{45}$ See, e.g., Tasioulas, "The Moral Reality of Human Rights"; Tasioulas, "Are Human Rights Essentially Triggers for Intervention?"; Tasioulas, "Taking Rigltts out of Human Rights."

46 See Tasioulas, "Taking Rights out of Human Rights."

77 On this connection, see Herbert Hart, "Are There Any Natural Rights?," in Jeremy Waldron

(ed.), Theories of Rights (Oxford: Oxford, 1984), 77-90, 79.

$4^{8}$ See Tasioulas, "Are Human Rights Essentially Triggers for Intervention?," 939 
how to get over this tension and therefore to reconcile fidelity with critique in the context of human rights theory. 49

Tasioulas's most explicit discussion of the legal dimension of human rights dates back to his paper The Moral Reality of Human Rights. $5^{\circ}$ There, he argues for the distinct moral existence of human rights independent from their legal recognition. He concedes that the law may in some cases contribute to specify human rights and play a vital role in their implementation, but understands their existence as determined by moral reasoning only..$^{51}$ In the course of his argument, Tasioulas targets manifesto-rights objections, particularly Raymond Geuss's enforceability critique and Onora O'Neill's claimability objection. In that context, he discusses the legal dimension of human rights, but as part of human rights' enforcement mechanisms or as part of the ways of making those rights claimable..$^{22}$ The legal version of the claimability argument is famously reflected in Feinberg's "there ought to be a law" theory of moral rights. According to that theory, "A has a moral right to do $\mathrm{x}$ " is to be understood as "A ought to have a legal right to $\mathrm{x.}$. 53 In response, Tasioulas rightly argues that legality is not a guarantee of enforcement in practice, ${ }^{54}$ and further that legality cua enforceability can be defeated by other (including human-rightsbased) considerations such as the costs of legal enforcement in some cases, alternative modes of nonlegal enforcement, or legally condoned human rights abuses. 55

Tasioulas does not, however, consider the possibility for legal recognition to be a conceptual criterion of human rights' existence independent from legal enforceability or clamability. His position regarding the conceptual role of law in human rights theory is conditioned by the objection he is addressing, namely legal enforcement or legal enforceability as condition of the existence of human rights..$^{56}$ Once the legality of human rights is separated from their

4) One way may be to interpret his fidelity criterion as one of the two steps in Dworkinian interpretation. The difficulty with this move, however, is that it requires either a blanket acceptince of Dworkin's legal theory or a fully developed theory of interpretation of normative practices such as the human rights practice.

${ }^{\circ}$ Tasioulas, "The Moral Reality of Human Rights."

${ }^{11}$ Tasioulas, "The Moral Reality of Human Rights," 76-77.

${ }^{52}$ See Tasioulas, "The Moral Reality of Human Rights," 81-82, 84-88.

53 See Joel Feinberg, Problems at the Roots of Law: Essays in Legal and Political Theory (Oxford: Oxford, 2003), 45 .

54 See Tasioulas, "The Moral Reality of Human Rights," $84-85$

55 See Tasioulas, "The Moral Reality of Human Rights," 85

${ }^{6}$ This is particularly clear when he quotes Habermas, "Die Legitimation durch Menschenrechte," in connection to Feinberg's moral right to have a legal right, explored in Feinberg, Problenis at the Roots of Law, 45 (Tasioulas, "The Moral Reality of Human Rights," 84). Habermas' point when he argues for the inherently legal nature of human rights is a conceptual enforcement, the question becomes more interesting, but it remains unanswered by Tasioulas to date. One may venture, however, that his answer to the conceptual connection between human rights and the law would be negative. This seems to be the upshot of his discussion of the "ordinary discourse of moral rights"s7 that is used well before a moral right becomes law and often against the law itself. $5^{8}$ Interestingly, Tasioulas moves imperceptibly from moral rights to moral human rights in the course of that discussion. As I will argue later on in this chapter, this is a crucial distinction; although it is true that not all universal moral rights correspond to legal rights and vice versa, one may argue differently in the context of human rights.

\section{B. Political Theories of Human Rights and the Law}

Political theories of human rights react to ethical accounts by understanding human rights not as universal moral norms - that would cover too many moral rights and fail the political reality test - but as politically adopted norms that constitute recognized limits on state sovereignty in current international relations. Despite being a sobering practice-based reaction to ethical accounts and in spite of their success in accommodating contingent factors such as the legal enactment of human rights, political theories of human rights ultimately pay very little attention to the legal nature of human rights. The first political account of human rights of this kind was Rawls's in his Law of Peoples in 1999. It has since been criticized and refined. In this section I address two of the most recent political accounts of human rights: those of Joseph Raz and Charles Beitz.

Joseph Raz's provocative argument in Human Rights without Foundations is that (moral and universal) human rights have no foundations, or at least none of the kind proposed by ethical accounts à la Griffin or Tasioulas. 59 There are universal nnoral rights that exist independently from their political

one, however, and not a normative one; it ought not be conflated with Feinberg's or, most recently, Raz's (additional) normative argument about a duty to recognize or enforce human rights legally (Raz, "Human Rights in the Emerging World Order"). I will come back to this central question in Section II.B.

57 See Tasioulas, "The Moral Reality of Human Rights," 85

$5^{8}$ See Tasioulas, "The Moral Reality of Human Rights," 86.

5) See Raz, "Human Rights without Foundations," 322-327. See also most recently Raz, "Human Rights in the Emerging World Order." Curiously, despite having written extensively on legal and moral rights in the 1980 - see Joseph Raz, "Legal Rights," Oxford Joumal of Legal Studies 4 (1984): 1-21; "On the Nature of Rights," Mind 93 (1984): 194-214; and "Rights and Politics," Indiand Law Joumal 71 (1995): 27-44 - Raz had never written about human rights until his first 2010 piece. 
recognition, but human rights are those universal moral rights that are also recognized as constraints on national sovereignty by international institutions their violation justifies sanctions or other restrictions on state sovereignty, albeit not necessarily an international intervention

In his article, Raz is not very detailed about the role played by the law in the institutional recognition of human rights as international constraints on sovereignty. Its role is implicit and pervasive, however, given its central function in international institutions and in the context of international sanctions and intervention. The institutional recognition of human rights, which is a condition of existence of human rights, is usually understood by Raz to be legal as a result. ${ }^{60}$ Based on his previous work on the relationship between legal and moral rights, the connection between the two is actually plausible and likely to be transposable to the human rights context. In his most recent article Human Rights in the New World Order, Raz clearly makes the connection by making the legal recognition of human rights part of their moral nature and existence as human rights. He goes even further as he now argues that human rights are the universal moral rights that ought to be not only recognized by law, but also (fairly, efficiently, and reliably) enforced by law. "If they cannot be enforced, as there cannot be an "ought" without a "can," then the right in question may still be regarded as a universal moral right, but it is not a human right. Enforceability and legal enforceability more particularly have therefore become conceptual conditions for the existence of a human right in the Razian theory of human rights.

Among the critiques one may make to Raz's most recent restatement of his argument, one should start with the distinction between legal recognition or enactment and legal enforcement. This is the same distinction I said was missing in Tasioulas's argument (for reasons pertaining to the positions he was arguing against). Here, however, one may have wished for a clearer justification as to the conflation between the two, especially because the early Raz made legal recognition only a condition of existence of human rights. Raz's argument is a normative one: The fact that human rights are a subset of universal moral rights we have independently of the law explains why the law has the same duty to recognize them as we all do individually independently from the law. Obviously, legal enforceability implies legal enactment for Raz, but one may question the additional requirement of enforceability once a human right is legally enacted. Raz's position regarding the normative requirement of legal enforceability is reminiscent of the arguments made by Geuss, O'Neill,

\footnotetext{
${ }^{60}$ See Raz, "Human Rights without Foundations," 326, 328-329, 336-337.
}

"See Raz, "Human Rights in the Emerging World Order." and Feinberg. As a result, it can be subjected to the objections made by Tasioulas regarding enforceability and legal enforceability in particular. ${ }^{62}$ The main critique has to do with the normative side of human rights and, in particular, with the specification of the corresponding duties. As a matter of fact, Raz himself argues that ethical theories underestimate the normative side of human rights. As we will see, however, human rights preexist logically to the specification of their corresponding duties in given circumstances. This is actually a conseguence of Raz's interest-based theory of rights. As a result making their existence and legal recognition depend on their enforcement would be conceptually self-defeating. True, making it depend not on their enforcement but on their enforceability, especially a fair, reliable, and efficient one, would be less problematic from a conceptual perspective. Nonetheless, it would still be largely indeterminate. ${ }^{{ }_{3}}$ This has to do both with the context sensitivity of those duties and with the deep indeterminacy that stems from the limited resources available, and the priorities that have to be made whenever a right is applied and its specific duties are identified. Conditioning the existence of human rights on their enforceability presumes the determinacy of their duties and therefore undermines the whole idea of a human right.

Of course, Raz may argue that legal enforcement is fairer, more efficient, and more reliable overall than other social and political means of enforcement. The normative pull for enforcement will be stronger if it derives from a legal duty than from a mere moral one, and as a result the moral duty to recognize and protect will be better respected through a duty of legal enforcement which itself would depend on legal enforceability given the "ought implies can" argument. However, one may still object to Raz's focus on international law, knowing that human rights have to be enforced in priority at the domestic level and then only subsidiarily by international institutions. This critique was put to him regarding his previous account as putting the cart before the horse. ${ }^{64}$ However, it has even more teeth now that legal enforceability itself and not only legal recognition and enactment have become part of his conceptual account of human rights. Raz's failure to conceive of human rights as moral and legal norms that bridge the national-intemational divide is puzzling from a human rights lawyer's perspective, given his resolution to provide a human rights account that fits the practice of human rights.

${ }^{62}$ See Tasioulas, "The Moral Reality of Human Rights," $84-85$. See also Thomas Pogge, "Human Rights and Hunan Responsibilities," in Andrew Kuper (ed.), Global Responsibilities: Who Must Deliver on Human Rights (New York: Routledge, 2005), 3-35, 12-14.

$6_{3}$ On the indeterminacy of human rights and duties, see Buchanan, Justice, Legitimacy, and

Self-Determination, 180-190; Tasioulas, "The Moral Reality of Human Rights," 93-94 ${ }^{6}+$ See Forst, "The Justification of Human Riglits." 
A final critique of Raz's requirement of legal enforceability pertains to the unilateral nature of the argument: Moral human rights only exist if they are legally enforceable. The impact of the legal recognition of one's interests qua human rights on the preexisting universal moral right is not discussed by Raz. It may, however, affect the interests protected, their balance, and the best way to enforce them in the future. Our moral interests and duties are not isolated from our social, political, and hence legal practices, especially when they pertain to our coexistence with other individuals. Although one may explain Raz's approach by reference to his political account of human rights and the fact that it is based on contingent factors in the human rights practice, it does not fit well with his previous work on the legal creation of certain moral rights. By fiat, he states that he is only concemed with legal rights that recognize preexisting moral rights and classifies human rights among them. He adds that this is what legal human rights are (rightly) considered to be. He does not, however, offer a normative argument for that choice, and for not considering how the law may not only recognize but also specify independent moral rights at the same time. ${ }^{65}$ This is regrettable, as one of Tasioulas's arguments against Raz's political account of human rights is precisely what Tasioulas refers to as the "parasitic" nature of the Razian account on traditional ethical theories of human rights. ${ }^{66}$ Raz cannot simply posit that human rights correspond to independent universal rights that ought to be legalized and not explain how that legalization relationship works.

Charles Beitz's recent book The Idea of Human Rights builds on his previous work on human rights but also revises it to a certain extent. ${ }^{67}$ The book defines itself as a theoretical examination of human rights qua central idea to the international or global political practice of human rights as it has gradually emerged as a legacy of World War II. According to Beitz, human rights are matters of international concern whose violation by governments can justify international protective and restorative action ranging from intervention to assistance. Beitz's political or practical account of human rights severs any link to morality and moral rights. In this sense, Beitz's human rights theory

${ }^{65}$ This is even more surprising as Raz, "Human Rights in the Emerging World Order," connects the contingency of human rights (qua legally recognized moral rights) to general features of all rights. Also, when he discusses that contingency, it is actually in relation to legally created moral rights only.

${ }^{66}$ See Tasioulas, "Are Human Rights Essentially Triggers for Intervention?"

${ }^{67}$ See Beitz, The ldea of Human Rights. See also Charles R. Beitz, "Human Rights as a Common Concern," American Political Science Review 95(2) (2001): 269-282; Charles R. Beitz, "What Human Rights Mean," Daedalus 132 (2003): 36-46; Charles R. Beitz, "Human Rights and the Law of Peoples," in Deen K. Chatteriee (ed.), The Ethics of Assistance: Morality and the Distant Needy (Cambridge: Cambridge, 2004), 193-216. differs from its main competitors: ethical or traditional theories of human rights as developed by James Griffin or John Tasioulas on the one hand and political or practical theories of human rights as put forward by John Rawls or Joseph Raz on the other. It differs from the former in that the author does not regard human rights as a subset of universal moral rights, but as a sui generis normative practice that protect individuals' urgent interests against standard threats posed to them by their (state) governments, including failure by the latter to regulate the conduct of agents of which they are responsible. ${ }^{68}$ Beitz does not, however, side with other political or practical accounts of human rights, despite sharing the same Rawlsian practical starting point. For him, human rights violations are not conceived as essentially triggers for international intervention, but only as a cause for international concern, which he understands as a broader protective and restorative notion..$^{69}$

Although one may be sympathetic to Beitz's practical approach and his definition of human rights as a normative concept to be grasped by understanding its role within the practice as opposed to an independent philosophical idea that would sit uneasy with the practice, one is left wanting more. More specifically, and although it is nonethical and political, Beitz's concept of human rights curiously seems to be a nonlegal one. Mentions to the legality of human rights are limited to historical references to legal human rights instruments and hence to positive human rights law in the book's second chapter. This is regrettable on more than one count. ${ }^{\circ}$

To start with, Beitz offers no detailed philosophical account of what he means by "normative practice," and legal theory may have helped in this respect. He describes humnan rights practice as being "both discursive and political"71 and, in a first approximation, defines it as "a set of norms for the regulation of the behaviour of states together with a set of modes or strategies of action for which violations of the norms may count as reasons." ${ }^{2} 2 \mathrm{He}$ also says that human rights are a normative concept that plays a normative role in practice by asking for some kinds of actions. ${ }^{73}$ Beitz states, however, that he knows of no good systematic method of interpretation for social practices and therefore has to proceed informally. ${ }^{74}$ This is surprising, because the law has been famously and repeatedly described by many legal theorists as a normative practice. Although Beitz is right not to equate human rights only

Sh See Beitz, The Idea of Human Rights, 109. ${ }^{69}$ See Beitz, The Idea of Human Rights, 109. 70 The discussion that follows is borrowed from a review of Beitz's book: See Samantha Besson, "Human Rights qua Normative Practices - Sui generis or Legal?," "Transnational Leyal Theory 1:1 (2010): 127-133.

Beitz, "1'he Idec of Human Rights 8

73 Beitz, The ldea of Huntan Rights, 9 .
72 Beitz, The Idea of Human Rights, 8. 7t Beitz, The Idea of Human Rights, 107 
with human rights law, the latter does constitute an important part of human rights practice and a part that is intimately connected to the other social and political dimensions of the practice. 75 Therefore, one may have expected to learn from Beitz how human rights differ from law as normative practice or how at least their legal dimension relates to their broader normative nature. True, Beitz mentions Ronald Dworkin's theory of legal interpretation in a footnote. There he says that he does not believe that that method is entirely suited for the task at hand, but he camnot discuss the reasons for his position..$^{7}$ Beitz's model of interpretation and his "schema" are very similar to Dworkin's, however. 77 Although Dworkin's theory may have deserved more than an excuse in a footnote, there are many other elements in legal theory that pertain to the creation of norms through practice that may have come in handy in Beitz's methodological account..$^{78}$ Of the many places in the book where this would have been the case, one may mention, for instance, his account of the ways to reconcile the practical and critical nature of human rights and to explain their middle-ground position in practical reasoning. ${ }^{79}$

More precisely, legal theory could also have helped Beitz define the nature of human rights by comparison to other kinds of nomative practices and, in particular, in explaining whether they are rights at all. First of all, if human rights practice is normative in that it can provide reasons for action but is neither purely moral nor purely legal, then Beitz has to explain in what sense it may be said to be nommative, even in a sui generis sense of normativity. 80 This is at least the case if human rights are understood as more than prudential considerations. One may indeed question the possibility of the existence of reasons for action outside of law and morality. Beitz defines human rights as protecting urgent or important interests. Even though he explains in detail what those interests are, ${ }^{{ }^{8}}$ he is evasive about how one gets from those interests to al specific kind of moral entity, namely rights. Maybe Beitz's humann rights are not rights at all, but it would be interesting to know why it is the case and why they are referred to as rights. If they are rights, it would have been

75 Some passages in Beitz, The Ided of Human Rights (e.g., pp. 40-42) seem to indicate the contrary, however. This is even more striking as the account of human rights Beitz puts forward (109) is largely geared toward the international legal regime of human rights, in terms of right holders and duty bearers and of their normative consequences in particular.

${ }^{76}$ Beitz, "'the ldea of Human Rights, 107 fin. 19.

77 Beitz, 'The Idea of Human Rights, 107-108 and 199.

${ }^{\gamma}$ For instance, Beitz's discussion of what a normative practice is and how to theorize it normatively and not descriptively on pp. 104-105 is reminiscent of well-known legal theoretical debates about the nature of law and of legal theory.

79 Beitz, The Idea of Human Rights, 105-106. So Beitz, The ldea of Human Rights, 197 useful to distinguish them in more detail from moral and legal rights and their complex relationship. Some answers to those questions could be found in Beitz's views on the duties corresponding to human rights. When discussing the supply side of human rights, however, Beitz is very cautious and refers either to responsibilities for first-level agents or to pro tanto reasons for secondlevel agents, and only very rarely to duties. ${ }^{82}$ He states earlier on in the book, however, that "[i]t is natural to think of international human rights as a type of moral right, and of moral rights as grounds for the assignment of duties to particular agents." ${ }^{3}$ Clearly, if Beitz's human rights do not give rise to duties, or at least not in all cases in which they give rise to reasons for action, their nature as rights has to be accounted for - or else it is the concept of rights itself that has to be fleshed out to accommodate those sui generis rights.

An explanation for Beitz's neglect of the legal dimension of human rights may be found in the last few pages of the book, where he discusses human rights as background norms of the global normative order. ${ }^{8} 4$ There his reasons for clistrusting the law become clearer, although they may be contested.

To start with, Beitz seems to endorse Martti Koskenniemi's postmodern assessment of international law as "bent to the advantage of stronger powers." 85 Although one may share those concerns about power in intennational relations, disparaging the whole international legal enterprise in one paragraph on that basis may be too quick, especially in the human rights field. International law has built-in correctives, for one thing. Beitz actually shows in the next paragraph that he is aware of those and refers to them as intemational legal actors' "normative discipline." He quickly moves on to the human rights practice's internal normative discipline, however, claiming it is more inclusive, but without explaining how it may connect to the internal discipline of international law itself. As a matter of fact, one may argue, following Allen Buchanan's interesting proposal in this respect, that international human rights' legal institutions may actually contribute to inclusive deliberation about human rights and hence to gradually weaken the bite of the cultural parochialism critique of human rights. ${ }^{86}$

Another explanation for Beitz's lack of interest for the legal dimension of human rights stems from his binary approach to both law and morality: He sees human rights as either moral or practical, and as either legal or practical. This approach underestimates the complex nature of most of our

$8_{2}$ Beitz, The Idea of Human Rights, $115-116$, but note 117 .

${ }^{83}$ Beitz, The Idea of Human Rights, $45 . \quad{ }^{8}$ Beitz, The Idea of Human Rights, 209-212.

${ }^{56}$ Beitz, The lded of Human Rights, 211

66 See Allen Buchanan, "Human Rights and the Legitimacy of the International Order," Legal
'Theory 14 (2008): 39-70. 
normative practices today, and more specifically the hybrid nature of the legal practice itself. Although it is true that the content of international legal human rights is not legally determinate and the justification for their authority is no purely legal, ${ }^{87}$ these are two characteristics of legal norms, and even more so of legal rights, that actually make them nomatively rich and interesting No one, not even an exclusive legal positivist, expects the law to be entirely determinate without references to morality and to generate duties to comply that are morally independent. ${ }^{88}$ Furthermore, Beitz offers a skewed view of the law at times. For instance, he understands it as precluding disagreement and imposing clear-cut or uncontested inferences. ${ }^{89}$ Again, modern legal theory has uncovered how the law channels disagreement and organizes agreements to disagree. ${ }^{\circ}$ This is particularly the case with human rights that provide for intermediary agreements on the importance of certain interests and the way to balance them, but at the same time leave many conflicts open and the specification of duties to further debate. ${ }^{93}$ One may even argue that the legal guarantees of human rights actually ensure that certain debates take place in society.

\section{THE NATURE OF HUMAN RIGHTS}

This brief survey of the major human rights theories defended in recent times has shed some light on some of the difficulties that human rights theorists face when accounting for the legal dimensions of human rights.

I propose to remedy the gap those accounts have generated between the ethical and political dimensions of human rights by developing a moralpolitical account of human rights. By reference to human rights' moralpolitical nature, my proposal regarding those rights' legalization bridges the separation between ethical and political theories of human rights. It is the political function of human rights, I will argue, that makes the connections between law and morality more central to them than to other legal norms. The pivotal role of human rights in politics also enables the proposed account to

87 Beitz, The ldea of Human Rights, 210.

ss See, e.g., Joseph Raz, "About Morality and the Nature of Law"; Waldron, "Judges as Moral Reasoners."

s) Beitz, The ldea of Human Rights, 210-211.

"See Jeremy Waldron, Law and Disdgreement (New York: Oxford, 1999); Samantha Besson, 'The Morality of Conflict. Reasonuble Disagreement and the Law (Oxford: Hart, 2005).

Law and Philosophy Nature of Rights," 208-209; Andrei Marmor, "On the Limits of Rights," haw and Philosophy 16 (1997): 1-18, 15-16; Samantha Besson, "Conflicts of Constitutional Rights: Nature, Typology and Resolution," in 'The Morality of Conflict, Chapter 12. explain the role of human rights in domestic and international law at the same time. This, in turn, helps explain some issues in human rights theory that are difficult to resolve, such as human rights constraints on state sovereignty, for instance. ${ }^{92}$

I start by arguing that human rights can be understood as moral propositions, and more specifically as universal moral rights that ground moral duties (Section II.A). Then I explain how human rights can also be described as legal rights, once the fundamental interests that found human rights are legally recognized. I also explain how those legal rights relate to the moral rights they recognize, modulate, or create (Section II.B).

\section{A. Moral Human Rights}

Human rights are part of morality, just as reasons, values, duties, principles, or interests are. They ought not, however, be identified with any or all of the latter nor taken to exhaust morality. In particular, human rights are of value and can be justified on the basis of values, but they are not themselves values. In short, human rights are a subset of universal moral rights (a) that protect fundamental and general human interests against (b) the intervention, or in some cases nonintervention, of (c) national, regional, or international public institutions. I present those three elements in turn.

To start with, let us state that a human right exists qua moral right when an interest is a sufficient ground or reason to hold someone else (the duty bearer) under a (categorical and exclusionary) duty to respect that interest visà-vis the right holder. ${ }^{93}$ For a right to be recognized, a sufficient interest must be established and weighed against other interests and other considerations with which it might conflict in a particular social context. 94 Rights are, in this conception, intermediaries between interests and duties. 95 It follows, first of all, that a right may be recognized and protected before the duties that correspond to it are specified. ${ }^{96}$ Once a duty is specified, it will be correlative

92 See Samantha Besson, "Whose Constitution(s)? International Law, Constitutionalism and Democracy," in Jeffrey L Dunoff and Joel Trachtman (eds.), Ruling the World? Constitutionalism, Intemational Law and Global Govemance, (Cambridge: Cambridge, 2009), 381-407. See also Patrick Macklem, "What Is International Human Rights Law? Three Applications of a Distributive Account," McGill Law Journal 52 (2007): 575-604; Cohen, "Rethinking Human Rights," 598 on the political role of international human rights.

"3 Raz, "On the Nature of Rights," 195.

"4 See Raz, "On the Nature of Rights," 200, 200.

"5 See Raz, "On the Nature of Rights," 208.

${ }^{96}$ See Neil MacCormick, "Rights in Legislation," in Peter Hacker and Joseph Raz (eds.), Law, Morality and Society: Lissays in Homour of H.L.A. Hart (Oxford: Oxford, 1977), 189-209, 201. 
to the (specific) right, but the right may preexist abstractly without its specific duties being identified. The relationship between rights and particular duties is therefore justificatory and not logical. ${ }^{97}$ As a result, the determination of the duty bearer(s) of a right and its claimability are not conditions of the existence of a moral right. $9^{8}$ Second, a right is a sufficient ground for holding other indivicluals under all the duties necessary to protect the interest rather than in terms of the details of these duties. 99 It follows that a right might provide for the imposition of many duties and not only one. Rights actually have a dynamic nature; successive specific cluties can be grounded on a given right, depending on the circumstances. ${ }^{100}$ This application indeterminacy of rights also implies that rights have to be localized to be fully effective; it is only in local circumstances that the allocation and specification of duties can take place. ${ }^{101}$

Turning to the second element in the definition, let us state that human rights are moral rights of a special intensity, in that the interests protected are regarded as fundamental and general human interests that all human beings have by virtue of their humanity and not by virtue of a given status or circumstance. They include inclividual interests when these constitute part of a person's well-being in an objective sense. That person need not believe that it is the case for her or his interest to require protection as a human right. Those interests also extend to others' interests in the community and even to common goods in some cases. ${ }^{102}$ In certain circumstances, those external interests can actually help boost the importance of an individual interest and justify the recognition of that interest as a human right. ${ }^{103}$ The fundannental nature of the protected interests will have to be determined by reference to the context and time rather than established once and for all. ${ }^{104}$ This is particularly important not only from the perspective of value pluralism but also of social

"7 See MacCormick, "Rights in Legislation," 199-202; Raz, "On the Nature of Rights," 196, 200

us See Tasioulas, "The Moral Reality of Human Rights"; contra Onora O'Neill, "The Dark Side of Human Rights," International Affairs 81() (2005): 427-439; Susan James, "Rights as Enforceable Clains," Proceedings of the Aristotelian Society 133 (2003): 133-147; Joel Feinberg, Social Philosophy (Englewood Cliffs, NJ: Prentice-Hall, 1973).

\%) See Jeremy Waldron, introduction to Theories of Rights, 10-11.

${ }^{100}$ See Raz, "On the Nature of Rights," $197-199$.

${ }_{100}$ See Buchanan, /ustice, Legitimacy, and Self-Detemination, 180-186

${ }^{102}$ See Joseph Raz, "Rights and Individual Well-Being," Ratio /uris 5 (1992): 127-142, 135.

${ }_{103}^{10}$ See Nickel, Making Sense of Human Rights.

"2 See, on the ahistorical and synchronic universality of human rights, Tasioulas, "Human Rights, Universality and the Values of Personhood"; Tasioulas, "The Moral Reality of Human Rights", 76-77. Contra Griffn, "First Steps in an Account of Human Rights"; Griffin, On Human Rights. See also Raz, "Human Rights in the Emerging World Order." pluralism, because human rights may protect a variety of different interests whose specific orderings may vary, depending on the context. ${ }^{105}$

What makes it the case that a given individual interest is regarded as sufficiently fundamental or important to generate a duty and that, in other words, the threshold of importance and point of passage from a general and fundamental interest to a human right is reached, may be found in the normative status of each individual as an equal member of the moral-political community. ${ }^{106}$ A person's interests merit equal respect in virtue of her or his status as member of the community; those interests are sociocomparatively recognized as important by members of the community and only then can they be recognized as human rights. This is done mutually and not simply vertically. As a result, human rights are not externally promulgated as such but mutually granted by members of a given political community. ${ }^{107}$ However, human rights are not merely a consequence of the equal status of individuals; they are also a way of actually earning that equal status and consolidating it. Without human rights, political equality would remain an abstract guarantee; through human rights, individuals become actors of their own equality and members of their political community. ${ }^{108}$ Therefore, human rights are power mediators ${ }^{109}$ : They both enable political equality and stem from it. Human rights and political equality are mutually interdependent, in other words. This relationship to political equality explains how human rights are intrinsically connected to democracy as well. ${ }^{110}$

105 See Tasioulas, "The Moral Reality of Human Rights," 95-98, 99-101. On the parochialism criticue of human rights, see also Besson, "The Legitimate Authority of International Human Rights."

${ }^{106}$ See Forst, "The Justification of Human Rights"; Forst, "The Basic Right to Justification," 48. On the relationship between political equality and human rights more generally, see Thomas Christiano, 'The Constitution of liquality (Oxford: Oxford, 2008), 138, 156 on public equality as ground for liberal rights; and Allen Buchanan, "The Egalitarianism of Human Rights," Ethics 120 (2010): 679-710; Buchanan, "Philosophical Theories of Human Rights," on the egalitarian dimension of international human rights.

${ }^{107}$ See Joshua Colhen, "Minimalism about Human Rights: The Most We Can Hope for?," The Journal of Political Philosophy 12(2) (2004), 190-213, 197-198; Forst, "The Justification of Human Rights."

${ }^{108}$ See Cohen, "Minimalism about Human Rights," 197-198; Cohen, "Rethinking Human Rights," $585-586$.

${ }^{109}$ For the original idea of mediating duties, see Henry Shue, "Mediating Duties," Ethics 98 (1988): 687-704, 703. See also Christian Reus-Smit, "On Rights and Institutions," in Beitz and Goodin, Clobal Basic Rights, 25-48, on human rights and power mediation. On liberal rights and the exercise of power in general, see Christiano, The Constitution of Equality, 134.

${ }^{10}$ See on those different kinds of relationship between human rights and democracy, Samantha Besson, "The Human Right to Democracy - A Moral Defence with a Legal Nuance," in Souveraineté populaire et droits de l'homme, Collection Science et Technique de la Société 
It is important to pause at this stage and clarify what is meant by political membership or inclusion into an organized political society. This will then enalble me to clarify how it is neither a parochial nor an exclusive criterion, and how it can account for both the universality and the generality of human rights.

Political membership is a normative idea according to which a person's interests are to be treated equally and taken into consideration in the decisions taken by a given political group. ${ }^{11}$ Human rights protect those interests tied to membership and whose disrespect would be tantamount to treating them as outsiders. Of course, some human rights are more closely tied to actual membership, whereas others such as the right to life, for instance, are closer to basic clemands of humanity. Even the latter rights, however, constrain what equal membership can mean if it is to be legitimate and the kind of interests it must protect. This is in line with the republican idea of the political community as locus of rights. ${ }^{122}$ It is a development of Hannah Arendt's argument relative to the right to have rights; according to that argument, the first human right is to the right to be an equal member of a community through which all other rights can be protected. ${ }^{113}$ By submitting individuals to genocide, torture, and other extreme forms of cruel treatment, a community excludes them and no longer treats them as equal members, thus violating the precondition of all human rights: political equality. ${ }^{124}$ The universality of human rights lies precisely in the universality of political membership in this normative sense. Their content and corresponding duties are institution dependent and in that sense contingent, but that is the result of the universality of political equality

(Strasbourg: Editions du Conseil de l'Europe, 2010; available at http://www.venice.coe.int/ docs/2010/CDL-UD\%282010\%29003-e.pdF).

"The following argument is a development the argument in Cohen, "Minimalism about Human Rights," $197-198$

"The proposed account comes very close to Forst, in his "The Justification of Human Rights"; "The Basic Right to Justification," 48-50; and Das Recht auf Rechtfertigung. My account differs, ultimately, because Forst's account is based on a reflexive right to political justification, whereas my account is based on political equality and its mediation through human rights (see also Christiano, 'The Constitution of Equality, 156). Both accounts, of course, rely on Habermas' idea of co-originality between democratic sovereignty and human rights. See Jürgen Habermas, Faktizität und Celtung. Beiträge zur Diskurstheorie des Rechtes und des demokratischen Rechtsstads (Frankfurt: Suhrkamp, 1992), Chapter III, although they provide different variations of that idea, notably by referring to an external right or walue provide dation for their co-originality. See Corey of Self-Covernment (Princeton, NJ: Princeton, 2007), 29-38 for a similar use of Habermas's
co-originality.

"See Hannah Arendt, "The Decline of the Nation-State and the End of the Rights of Man," in The Origins of Totalitariunism (London: Penguin, 1951); Cohen, "Rethinking Human Rights," 604 fn. 47 .

${ }^{114}$ As a result, it is not possible to distinguish, among human rights, between those that are comnected to political equality and to democracy and those that are not. and of the standard threats of politics. ${ }^{115}$ This second criterion is compatible, in other words, with the universality of human rights and cannot be deemed parochial.

Of course, there can be many overlapping political communities, and this argument is not limited to a national polity and to the state. Nor is the argument limited to citizen's rights; membership ought to include all persons who are fundamentally affected by the activities of political authorities and who are subjects to the laws or decisions of the community. This includes asylum seekers, economic migrants, stateless persons, and so on. Nor does it imply that human rights only apply within national borders; if national political authorities affect the fundamental interests of other individuals outside their borders, then those individuals deserve equal protection. This includes individuals and groups fundamentally affected by military and by economic intervention abroad. In this sense, the second criterion is in line with the generality of human rights, and it is not exclusive.

This brings me to the third element in the definition: Human rights are entitlements against public institutions (national, regional, or international) ${ }^{116}$ They generate duties on the part of public authorities not only to protect equal individual interests, but also to protect individuals' political status as equal political actors. Public institutions are necessary for collective endeavor and political self-determination, but they may also endanger them. Human rights enable the functioning of those institutions in exchange for political equality and protection from abuse of political power. This is why we can say that humnan rights both are protected by public institutions and provide protection against them; they exist because of collective endeavor in order both to favor and constrain it. ${ }^{17}$ Of course, other individuals may individually violate human rights and ought to be prevented from doing so by public institutions and, in particular, through legal means. ${ }^{118}$ This ought to be the case whether those individuals' actions and omissions may be attributed to public authorities or not as de jure or de facto organs. However, public institutions remain the primary addressee of human rights claims and the primary duty bearer. ${ }^{119}$

"5 For a similar argument, see Forst, "The Basic Right to Justification," 49.

${ }^{116}$ This makes my account of moral human rights both transnational and international, in the sense that they are standards that apply in all domestic political communities but also among agents who are not members of a domestic political comnunity - of course, they are to the extent that the international community can be considered a political community.

${ }^{117}$ See Allen Buchanan, "Equality and Human Rights," Politics, Philosophy G Economics 4 , (2005): 69-90, 74 .

"18 See Shue, Basic Rights, on the different types of negative and positive duties corresponding to a human right, including duties to prevent other agents from violating it.

119 This normative argument actually corresponds to the state of international hunan rights law that only directly binds states or international organizations to date and no other subjects 
In short, the proposed account of the nature of human rights follows a modified interest-based theory: It is modified by reference to considerations of equal moral-political status in a given community. Under a purely status-based or interest-based model, the Manichean opposition between the individual and the group, and between his or her private and public autonomy, would lead to unjustifiable conclusions. ${ }^{120}$ More specifically, the proposed account is mora in the independent justification it provides for human rights and political in the function it sees them vested with: They are incleed regarded both as shields against the state and as guarantees of political inclusion. In terms of justification, its moral-political dimension differs not only from accounts based on a purely ethical justification of human rights, but also from accounts that seek a political form of minimalist justification of human rights. ${ }^{121}$ In other words, the proposed moral-political account of human rights can salvage the political role of human rights without diluting their moral justification. ${ }^{122}$ This is what their moral-political nature captures.

\section{B. Legal Human Rights}

It follows from the moral-political nature of human rights that the law is an important dimension of their recognition and existence. To understand exactly how and to unpack the legal dimension of human rights, I first present their legality and then turn to their level of legalization, particularly to how one ought to understand their international legalization.

\section{The Legality of Human Rights}

Just as moral rights are moral propositions and sources of moral duties, legal rights are legal propositions and sources of legal duties. They are moral interests recognized by the law as sufficiently important to generate moral

(e.g., individuals and groups of individuals). As a matter of fact, states are the primary subjects that are legally bound by both the duty to obey those intemational law norns and by the rightbased duties contained in those norms. Of course, other subjects may be bound by the latter, but it will usually be on the basis of a duty to obey stemming fron domestic law or from other international law norms (e.g., Article 24 combined with Article iof the UN Charn for the UN), i.e., other state-issued legal norms. This is not to deny, of course that the sarter for the or values may have to be protected through other no as through interve to be protected through other norms of domestic or international law, such as through intemational humanitarian law or international criminal law, for instance. ${ }^{30}$ See Tasioulas's critiçue of Griffin, On Human Rights: Tasioulas, "Taking Rights out of Human
Rights."

"2ee Cohen, "Minimalism about Human Rights."

See also Forst, "The Justification of Human Rights"; Forst, "The Basic Right to Justification," duties. ${ }^{123}$ The same may be said of legal human rights: Legal human rights are fundamental and general moral interests recognized by the law as sufficiently important to generate moral duties.

Moral rights can exist independently from legal rights, but legal rights recognize, modify, or create moral rights by recognizing moral interests as sufficiently important to generate moral duties. ${ }^{124}$ Of course, there may be ways of protecting moral interests or even independent moral rights legally without recognizing them as legal rights. Conversely, some legal rights may not actually protect preexisting moral rights or create moral rights, thus only bearing the name of "rights" However, the same cannot be said of human rights. Universal moral interests and rights may be legally protected without being recognized as legal rights But, as we will see, human rights stricto sensu can only exist as moral rights qua legal rights. Conversely, one may imagine legal norms referred to as human rights that do not correspond to moral human rights. In such a case, the legal norms named "human rights" would only give rise to legal duties and not to moral (rights-based) duties. Legal human rights, however, can only be regarded as rights stricto sensu when their corresponding duties are not only legal but also moral.

Two remarks on the relationship between moral and legal rights and the relationship between moral and legal human rights are in order. The differences between rights and human rights on the one hand and between their respective moral and legal dimensions on the other can be quite important, given the moral-political nature of human rights and what this implies in turn for their inherently moral and legal nature.

${ }_{123} \mathrm{Raz}$, "Legal Rights," 12. For a recent restatement of his theory of moral and legal rights and their relationship, see Raz, "Human Rights in the Emerging World Order."

17 Legal recognition of human rights can therefore be taken to mean, depending on the context both the legal recognition of an interest as a human right and the legal recognition of a preexisting human right.

125 Note that this lack of perfect correspondence between legal and moral rights and duties ought not be confused with an inclusive legal positivist account of rights: It is not what makes the legal right "legal" and valid law that is relevant here, but what makes it a "right." See also Raz, "Human Rights in the Emerging World Order," who talks of the lack of "moral force" of legally created rights that do not correspond to moral rights. For a defense of exclusive legal positivism in view of the moral nature of legal reasoning and of the legal modulations or exclusions of morality, see, e.g., Raz, "About Morality and the Nature of Law"; and Raz, "Incorporation by

Note that this duty is the primary moral duty to protect the interest that founds the legal human right, and not the secondary moral duty to obey the legal norm "human right": see Besson, "The Legitmate Authority of International Human Rights." 
Not all moral rights are legally recognized as legal rights. There are many examples of moral rights that have not been recognized as legal rights. Nor should all moral rights be recognized and protected legally. Respect for them should be a matter of individual conscience in priority.

The same cannot be said about human rights, however. True, not all universal moral rights have been or are legally recognized as legal human rights Some are even expressly recognized as universal moral rights by the law even though they are not made into legal rights or modulated by the law. ${ }^{127}$ A distinct question is whether they ought to be legalized and, hence, protected by law. Again, respect for universal moral rights ought to be voluntary in priority, and this independently from any institutional involvement. Nonetheless, miversal moral rights create moral duties for institutions, and hence for the law as well, to recognize and protect human rights. ${ }^{128}$ This is an application of Feinberg's "there ought to be a law" theory of moral rights, albeit restricted to the field of human rights only. According to that theory, "A has a moral right to do $\mathrm{x}$ " is to be understood as "A ought to have a legal right to x." 129 Furthermore, legalizing universal moral rights is often justified by other reasons such as reasons of security and clarity, intermediary agreement on a contested right or set of interests, effectivity, sanctions, or publicity. ${ }^{130}$ Besides those nomative arguments external to human rights themselves, one may make an internal normative or conceptual argument for the legal enactment of human rights. Based on the moral-political account of human rights presented previously, the law provides the best, and maybe the only, way of mutually recognizing the comparative importance of those interests in a political community of equals. ${ }^{131}$ It enables the weighing of those interests against each other and the

${ }^{127}$ One may think here of the moral rights mentioned by the Ninth Amendment of the U.S. Constitution: "The enumeration in the Constitution, of certain rights, shall not be construed to deny or disparage others retained by the people." U.S. Const. Amend. IX.

${ }^{128}$ See Raz, "Human Rights in the Emerging World Order."

เ29 See Feinberg, Problenss at the Roots of Law, 45.

$13^{\circ}$ See, e.g., Robert Alexy, "Die Institutionalisierung der Menschenrechte in demokratischen Verfassungsstaat," in Gosepath and Lohmamn, Philosophie der Menschenrechte, 254: "Wenn es Menschenrechte als universelle, moralische, fundamentale, vorrangige und abstrakte Rech gibt, clamn ist ihre rechtliche Institutionalisierung sowohl auf der Ebene des internationalen als auch auf der des nationalen Rechts geboten" See also Gardbaum, "Human Rights international Constitutional Rights" "764-768. Forst "The Jutification of Human other arguments for legalization

"See Besson, "Conflicts of Constitutional Rights: Nature, Typology and Resolution," Chapter 12. See, e.g., Cohen, "Rethinking Human Rights," $599-600$; Forst, "The Justification of Human Rights"; Forst, "The Basic Right to Justification," 48-50. See even Pogge, "Human Rights and Human Responsibilities," fn. 26, who concedes this point in the case of civil and political rights. It seems, however, that the egalitarian dimension of human rights and hence their inherently legal nature would apply even more to the case of social and economic rights. drawing of the political ecjuality threshold or comparative line. In short, the law makes them human rights stricto sensu. As a result, in the moral-political account of human rights propounded here, the legal recognition of a fundamental human interest, in conditions of political equality, is part of the creation of a moral-political human right. In other words, while being independently justified morally and having a universal and general scope, human rights as subset of universal moral rights are also of an inherently legal nature. To quote Jürgen Habermas, "they are conceptually oriented towards positive enactment by legislative bodies." 32 Thus, although legal rights stricto sensu are necessarily moral in nature (as rights), human rights (as rights) are not only necessarily moral but also legal and they are as a result both moral and legal rights.

Note that the legal enactment' $t^{133}$ of human rights ought not be conflated with the requirement of legal enforcement or legal enforceability for the reasons discussed in the previous section. The institutionalization and enforcement of a human right are consequences of its recognition and not a condition of its existence. ${ }^{34}$ Duties still have to be specified once the human right is recognized, thus making their correlation depend on the justificatory priority of rights over duties. Legal human rights may be better enforced by other social and political means. ${ }^{135}$ Although legal enactment of human rights implies a further legal duty to enforce them legally and to institutionalize that enforcement, ${ }^{136}$ their moral and legal existence as human rights is not conditioned either by actual legal enforcement or by legal enforceability. It may be by the sheer feasibility of human-rights-correlative duties, ${ }^{137}$ provided their specific duties can be made determinate enough, but not by their legal enforceability.

Nor, in contrast, do legal rights necessarily always preexist as independent moral rights. Most do and are legally recognized moral rights, ${ }^{138}$ but others

132 Habermas, "Die Legitimation durch Menschenrechte," 183: "Als subjektive Rechte sins sie von Haus aus juristischer Natur und schon ihrem Begriffe nach auf eine Positivierung durch gesetzgebende Körperschaften angelegt'. See also Habermas, Faktizität und Celtung, 310-312. $133 \mathrm{~A}$ further question would be that of the kind and level of legal enactment (e.g., more or less entrenched). On this question, see Waldron, Law and Disagreement, Chapter 10; Besson, "Conflicts of Constitutional Rights"; Waldron, "Refining the Question," 72.

${ }^{134}$ Nickel, Making Sense of Human Rights, 33.

135 See, e.g., Waldron, Law and Disagreement, Chapter 10; Pogge, "Human Rights and Human Responsibilities," 12-14; Tasioulas, "The Moral Reality of Human Rights," $84-85$.

${ }^{136}$ See, e.g., Alexy, "Die Institutionalisierung der Menschenrechte"; Habermas, "Die Legitimation durch Menschenrechte".

, 137 See Tasioulas, "The Moral Reality of Human Rights," 93.

${ }^{138}$ The legalization of preexisting moral rights is rarely a mere translation; it usually specifies and somehow changes the moral right. See Saladin Meckled-Garcia and Başak Cali, "Lost 
are legally created or legally specified moral rights. ${ }^{139}$ In some cases, law and politics may affect a person's interests, thus in a sense enhancing the moral interest or its moral-political significance that are necessary for that interest to be recognized as a source of duties and hence as a right. One may think of zoning rights in the context of land planning, for instance, or of government bondholders' rights. ${ }^{240}$

The same cannot be said about legal human rights, however: All of them necessarily also preexist as independent universal moral rights. However, the law can specify and weigh moral human interests when recognizing them as legal human rights. One may imagine certain political interests whose moralpolitical significance may stem from the very moral-political circumstances of life in a polity. As a result, the law does not create universal moral rights, but it can modulate them when recognizing them. Furthermore, the inherently legal nature of human rights and the role the law plays in recognizing given interests as sufficiently important in a group as to generate duties and hence human rights make it the case that the law turns preexisting universal moral rights into human rights and hence actually makes them human rights. As a result, human rights cannot preexist their legalization as independent moral human rights stricto sensu, but only as independent universal moral rights.

\section{The Level of Legalization of Human Rights}

The legalization of human rights, that is, the legal recognition and modulation of universal moral rights qua human rights, can take place at the domestic or at the international level, namely through national or international legalization. ${ }^{14}$

in Translation: The Human Rights Ideal and International Human Rights Law," in Cali and Meckled-Garcia, The Legalization of Human Rights, 11-31; and Cali and Meckled-Garcia, "Introduction: Human Rights."

${ }^{139}$ See Raz, "Legal Rights," 16-17. See also Raz, "Human Rights in the Emerging World Order." 1+0 Both examples are given by Raz: See "Legal Rights," 16-17, "Human Rights in the Emerging World Order."

${ }^{41}$ International legalization covers all sources of international human rights law, ranging fron human rights treaties to customary international law and general principles. On the sources of international human rights law in general, see the two seminal pieces by Bruno Simm and Philip Alston, "The Sources of Human Rights Law: Custom, lus Couens and Genm Principles," Australian Yearbook of International Low Flauss, "La protection des droits de l'homme et les sour du protection des droits de l'humume et lévolution du droit ines droit international," in L. Société francase poure drot int lévolution du droit intermational. Colloque de Strasbourg Société française pour le droit international (Paris: Pedone, 1998), 11-79.
The locus of legalization of human rights ought to be domestic in priority. ${ }^{142}$ Given what was said about the interdependence between human rights and political equality, indeed, the political process through which their legalization takes place ought to be democratic and include all those whose rights are affected. As a result, using international law to recognize fundamental and general human interests as sufficiently important to generate state duties at the domestic level is delicate. Not only does international law making include many other states and subjects than those affected, but the democratic quality of its processes is not yet secured. ${ }^{143}$ The situation would be altogether different if the moral-political community bound by those legal human rights was an international one: The right holders and duty bearers would be the equal members, political actors, and law makers of that international comnunity. The European Union constitutes an interesting example of supranational political community where human rights and political equality can develop hand in hand beyond the state. ${ }^{144}$ That, however, is not what is usually aimed at in the context of international human rights law: Most international human rights instruments existing to date bind national authorities exclusively.

What this means, in other words, is that so-called international human rights can at least be regarded as legally protected universal moral rights and most of the time as legal rights as well. However, unless they refer to and correspond to existing domestic (moral-political and legal) human rights, they cannot be regarded as human rights for lack of a moral-political community. ${ }^{145}$ The solution would be to regard them as rights to have rights, that is, as rights to equal membership in a moral-political community. According to Arendt, the "right to have rights" is the only international human right and all other

${ }^{1+2}$ Contral O'Neill, "The Dark Side of Human Rights," 433, I do not understand international human rights duties only as second-order duties to secure or ensure respect for human rights, but also as first-order duties corresponding to those rights. See Besson, "The Legitimate Authority of International Human Rights."

${ }^{43}$ See, e.g., Thomas Christiano, "Democratic Legitimacy and International Institutions," in Besson and Tasioulas, Philosoplyy of International Law, 119-137 on the lack of representativity and the asymmetry of international law-naking processes from a democratic theory"s perspective See also Cohen "Rethinking Human Rights" 599-600. Besson, "The Legitimate Authority of International Human Rights."

"H On E.U. institutions as human rights duty bearers, however, see Samantha Besson, "The European Union and Human Rights: Towards a New Kind of Post-National Human Rights Institution," Human Rights Law Review 6(2) (2006): 323-360.

45 There is, in other words, a form of political parochialism or legal contingency of human rights that conditions their recognition as international legal human rights, well before parochialism arises as a problem for the scope of legitimacy of an existing legal human right. See also Raz, "Human Rights in the Emerging World Order"; and Buchanan, "Philosophical Theories of Human Rights" for a similar approach to human rights' conceptual contingency. 
human rights have to be guaranteed with in a political community. ${ }^{16}$ That right to have rights is a right to political equality and includes the right to all other human rights that make individuals equal members of the moral-political community. That right prohibits submitting individuals to genocide, torture, and other extreme forms of cruel treatment, through which a community excludes individuals and does not treat them as equal members. ${ }^{147}$

As a result, human rights guarantees in international law are usually minimal; they rely on national guarantees to formulate a minimal threshold, which they reflect and entrench internationally. ${ }^{1+8}$ More importantly, they are usually abstract and are meant to be fleshed out at domestic level, not only in terms of the specific duties attached to the right but also in terms of the right itself. ${ }^{149}$ Both levels of protection are usually regarded as complementary and as serving different functions, therefore, rather than as providing competing guarantees. This complementarity between international recognition and domestic politics explains why the national reception of international human rights within domestic law is often favored or ordered ${ }^{15}$ by international human rights instruments or chosen by states in practice. Domestic human rights law does more than merely implement international human rights; it contextualizes and specifies them. One actually often talks of "reception" within the domestic legal order in that respect. ${ }^{151}$ Through domestic legal reception, national authorities determine democratically what the actual threshold of importance of various human interests is to be and what duties that human right will give

$4^{6}$ See Arendt, "The Decline of the Nation-State." See also Cohen, "Rethinking Human Rigltss," 604 fn. 47; Forst, "The Justification of Human Rights."

147 See Cohen, "Rethinking Human Rights," 587.

${ }^{1+8}$ This is confirmed by the way in which democratic states usually ratify human rights instruments and, hence, generate international human rights duties for themselves only once they have recognized minimal international human rights standards in domestic law (e.g., Switzerland and the European Convention on Hunm Rights in the 1970s, and currently in the context of the ratification of the additional Protocol to the International Covenant on Economic, Social and Cultural Rights or the European Social Cliarter).

4f) It is important to note that the contextualization of human rights ought to take place through the form of domestic legal rights according to this chapter's moral-political argument. By contrast, indeed, some human rights anthropologists - such as Sally Engle Merry, Human Rights and Cender Violence: Translating International Law into Local Justice (Chicago: University of Chicago, 2006); Sally Engle Merry and Mark Goodale (eds.), The Practice of Humuan Rights: Tracking Law between the Clobal and the Local (Cambridge: Cambridge 2007) argig th: international human rights can sometimes be most effective if they a individual legil rights at the locil level.

internternational human rights instruments express state parties' positive duties to implement international human rights through domestic law (whether through domestic rights or not):
e.g., Article 4 U.N. Convention on the Rights of the Child.

'On this term, see Alec Stone Sweet and Helen Keller, introduction to A Europe of Rights. The Impact of the LCCHR on National Legal System.s (Oxford: Oxford, 2008), 3-30. rise to in practice. This explains why in the case in which domestic guarantees of the same human rights exist, international guarantees are usually subsumed to domestic ones in practice.

Of course, one may object that, in this minimal approach, international legal rights would be vacuous or at the most redundant. This, one may argue fails to explain why states adopt international human rights catalogues. However, this objection ignores the great variety of prudential and nomprudential reasons states may have to legally commit to human rights internationally, some of which may have nothing to do with human rights themselves, on the one hand. ${ }^{152}$ On the other hand, the role played by the minimal threshold constituted by international human rights is not to be underestimated; states commit, through international human rights and duties, to keep the level of human rights protection they have achieved domestically and not to fall back below that minimal threshold. Intenational human rights are guarantees against a leveling-down process, in other words. ${ }^{153}$ There is nothing vacuous as a result in international human rights minimalism. ${ }^{154}$ Quite the contrary: It corresponds not only to the current state of legality of international human rights but also to their moral reality.

This approach has the further benefit of explaining and coordinating the legal recognition of human rights at the domestic and the international levels. ${ }^{155}$ It puts intemational human rights law in context. State sovereignty and political self-cletermination are indeed one of the pillars of the international order, a pillar that is complemented and not replaced or restricted by international human rights law. ${ }^{156}$ In other words, the international legal order protects the interdependence between political equality and human rights alluded to before, by guaranteeing the basic conditions for political equality through state sovereignty and political self-determination on the one hand and the possibility to use them through human rights and the right to have rights on the other. This integrated or holistic account of the legality of human rights proposed in this chapter actually bridges a gap that has been

${ }^{152}$ See, e.g., Andrew Moravcsik, "The Origins of Human Rights Regimes: Democratic Delegation in Postwar Europe," International Organization 54(2) (2000): 217-252; Beth A. Simmons, Mobilizing for Human Rights: International Law in Domestic Politics (Cambridge: Cambridge, 2009).

153 There is an ingrained notion of progress in international human rights law, in other words. ${ }^{154} 4$ Contra Raz, "Human Rights without Foundations," Section IV.

155 On conflicts between international and national human rights and the question of the legitjmate authority and priority of the former over the latter, see Besson, "The Legitimate Authority of International Human Rights."

${ }^{156}$ See, for a similar argument, Macklem, "What is International Human Rights Law?," 577; Cohen, "Rethinking Human Rights," 595-597 
left open by the few human rights theories that have accommodated the legal dimension of human rights to date: those of Joseph Raz and Jean Cohen. As alluded to before, Raz's criterion of legal enforceability's7 is restricted to international legal enforceability. This creates difficulties when one is confronted with the domestic locus of enforcement in human rights practice. Along the same lines, Jean Cohen's proposal to transpose the Habermasian constitutional model to the international plane and to reconvene anew on international human rights ${ }^{158}$ curiously severs the very links to domestic politics her dualist account of international relations relies on. It introduces an artificial divide between the right to have rights that would be international and other human rights that would be clomestic, a divide that is unknown to contemporary human rights practice.

\section{CONCLUSION}

Curiously, recent theories of human rights, whether on the ethical or the political side of the debate, have had very little to say about the legality of human rights. With a few exceptions, they have made the law part of the many ways in which humann rights may be enforced after they have been ethically identified, or, on the contrary, part of the many ways in which human rights may be practically identified, but with no ethical moral significance. As a result, neither of them succeeds in bridging the gap between human rights as critical standards and human rights practice. This constitutes not only a gap in their accounts of the nature of human rights but also arguably an impoverishment for human rights theory.

After exploring different reasons for this legal neglect in human rights theory in the introduction, the chapter proceeded with a two-pronged argument. It started by assessing the legal dimension of the four main ethical and political human rights theories in the first section. In the second section, the chapter identified a middle way between those ethical and political theories of human rights and argued that the legal dimension of human rights could straddle both sides of the argument in a moral-political account of human rights. The

157 See Raz, "Human Rights in the Emerging World Order."

${ }_{158}$ See Colhen, "Rethinking Human Rights," $599-600$, based on Forst, "The Basic Right to Justifcation," 48-50; Forst, "The Justification of Human Rights" and Habermas, "Die Legitimation durch Menschenrechte," 183. Note that Forst, in "The Basic Right to Justification," 50 et sec. and "The Justification of Human Rights" (more cautious, though), seems to be defending an integrated approach to human rights, but he draws no clear line between the domestic and the international legalization of human rights and certainly does not provide a way to disentangle the domestic from the international political communities and their respective ho disentangle guarantees. proposed account of the nature of humann rights draws both from a republican theory of political membership and a legal theory of rights. On the basis of that account, I have argued, on the one hand, that human rights are inherently moral and legal: The law cannot create universal moral rights but it can recognize or even modulate them, and turn them into human rights stricto sensu. On the other, by virtue of human rights' close relationship to political equality, I ventured that the legalization of human rights ought to take place at a domestic level in priority. International human rights norms can only be regarded as human rights if they match, in a minimal way, an existing set of domestic humann rights. In the absence of such a set of domestic human rights, the only international legal human rights there can be stricto sensu are rights to have rights, that is, rights to political equality and membership with all the human rights those rights require for their realization in a given political community.

Although one may be legitimately concerned about the little attention devolved to ethics in the theory of international law to date, human rights theory seems to suffer from the reverse neglect: It is overly "ethicized" and has by and large underestimated the role played by the law both conceptually and normatively in humnan rights practice. The time has come to develop a legal theory of human rights that can account for the law's pivotal role in the recognition, specification, and legitimation of human rights. 